(c) American Dairy Science Association, 2006.

\title{
Effect of Amount and Ruminal Degradability of Soybean Meal Protein on Performance of Lactating Dairy Cows ${ }^{1}$
}

\author{
J. J. Olmos Colmenero*2 and G. A. Broderick ${ }^{3}$ \\ *Department of Dairy Science, University of Wisconsin, Madison 53706 \\ †Agricultural Research Service, USDA US Dairy Forage Research Center, 1925 Linden Drive West, Madison, WI 53706
}

\begin{abstract}
Twenty-eight Holstein cows (4 with ruminal cannulas) were blocked by days in milk into 7 groups and then randomly assigned to 1 of 7 balanced $4 \times 4$ Latin square diet sequences. The diets contained [dry matter (DM) basis] $20 \%$ alfalfa silage, $35 \%$ corn silage, and $45 \%$ concentrate mainly from high-moisture corn and soybean meal. Diets differed in crude protein (CP) content and source of protein supplement: $\operatorname{diet}$ A) $15.6 \%$ CP, $3.7 \%$ solvent-extracted soybean meal (SSBM), $4.5 \%$ expeller soybean meal (ESBM); diet B) $16.6 \%$ CP, $9.6 \%$ SSBM, 0\% ESBM; diet C) 16.6\% CP, 4.6\% SSBM, 5.9\% ESBM; and diet D) $17.6 \% \mathrm{CP}, 11.7 \%$ SSBM, 0\% ESBM. Each experimental period consisted of $14 \mathrm{~d}$ for adaptation plus $14 \mathrm{~d}$ for collection of production data. Sampling of ruminal digesta and spot sampling of blood, feces, and urine was done on d 26 and 27 of each period. Planned contrasts compared included $\operatorname{diet} \mathrm{A}$ vs. $\operatorname{diet} \mathrm{B}$, $\operatorname{diet} \mathrm{B}$ vs. $\operatorname{diet} \mathrm{C}$, and $\operatorname{diet} \mathrm{B}$ vs. $\operatorname{diet} \mathrm{D}$. There were no effects of diet on most of the production traits measured. However, milk yield tended to be higher for diet B vs. A. Trends were also detected for higher DM intake and weight gain and lower milk yield/DM intake in cows fed diet D vs. diet B. Milk lactose content was higher on diets $\mathrm{A}$ and $\mathrm{C}$ than on $\mathrm{B}$. Ruminal $\mathrm{NH}_{3}$ was higher on diet D vs. B, but other ruminal metabolites, apparent nutrient digestibility, and estimated bacterial CP synthesis did not differ across diets. Blood and milk urea$\mathrm{N}$ were higher on diets $\mathrm{C}$ and $\mathrm{D}$ than on $\mathrm{B}$; milk urea$\mathrm{N}$ was higher on diet $\mathrm{B}$ than on $\mathrm{A}$. Increasing dietary CP from $16.6 \%$ (diet B) to $17.6 \%$ (diet D) increased urinary $\mathrm{N}$ excretion by $54 \mathrm{~g} / \mathrm{d}$ and reduced apparent $\mathrm{N}$ efficiency (milk N/N intake) by 2.5 percentage units,
\end{abstract}

\footnotetext{
Received June 10, 2005.

Accepted November 10, 2005.

${ }^{1}$ Mention of any trademark or proprietary product in this paper does not constitute a guarantee or warranty of the product by the USDA or the Agricultural Research Service and does not imply its approval to the exclusion of other products that also may be suitable.

${ }^{2}$ Current address: Centro Universitario de los Altos, Universidad de Guadalajara, Carretera a Yahualica Km. 7.5, Tepatitlan de Morelos, Jalisco, Mexico CP 47600.

${ }^{3}$ Corresponding author: gbroderi@wisc.edu
}

without altering yield. Under the conditions of this trial, milk production was not improved by feeding rumen-undegraded protein from ESBM or greater amounts of rumen-degraded protein from SSBM. Feeding more than $16.6 \% \mathrm{CP}$ depressed $\mathrm{N}$ efficiency.

Key words: dietary crude protein, soybean protein, nitrogen metabolism, nitrogen excretion

\section{INTRODUCTION}

Ideally, dietary CP should supply adequate amounts of RDP for maximal formation of microbial protein that is of good quality for milk and protein production in terms of its AA content (NRC, 2001), plus adequate amounts of RUP with an AA pattern that is complementary to that of microbial protein for maximal productivity at minimal $\mathrm{N}$ waste. The NRC (2001) model predicts that the dietary $\mathrm{CP}$ concentration required for a specific level of milk production decreases when RUP is supplemented in the diet. If this approach were successful, efficiency of conversion of dietary $\mathrm{N}$ into milk protein would be improved and economic advantage would be gained due to reduced feed costs rather than increased production.

Supplementation of RUP has shown inconsistent effects on milk production when compared with soybean meal (Santos et al., 1998). However, some RUP sources, such as expeller soybean meal (ESBM), improved milk production when fed in diets that contained alfalfa silage (Broderick et al., 1990) or alfalfa silage plus corn silage (Reynal and Broderick, 2003). Recent studies (Broderick, 2003; Olmos Colmenero and Broderick, 2006a) have shown that, with diets based on alfalfa silage and corn silage and supplemented with solventextracted soybean meal (SSBM), maximal milk and protein production was achieved with about $16.5 \% \mathrm{CP}$. Any further increment in CP content of these diets only increased urinary $\mathrm{N}$ excretion and lowered $\mathrm{N}$ efficiency.

Therefore, the objectives of this study were 1) to determine whether production of dairy cows could be maintained at lower dietary $\mathrm{CP}$ and $\mathrm{N}$ excretion by partially replacing SSBM with ESBM, and 2) to test whether production could be improved by either increasing dietary RUP by partially replacing SSBM with 
ESBM at the same CP level or by increasing the dietary CP by feeding more SSBM.

\section{MATERIALS AND METHODS}

\section{Experimental Procedure}

Twenty-eight multiparous Holstein cows averaging 129 DIM (SD 66), 2.8 parity (SD 1.0), $656 \mathrm{~kg}$ of BW (SD 43 ), and $41 \mathrm{~kg}$ of milk/d (SD 7) at the start of the trial were blocked by DIM into 7 groups; cows in 1 group were fitted with $10-\mathrm{cm}$ ruminal cannulas. Within groups, cows were randomly assigned to 7 balanced 4 $\times 4$ Latin square diet sequences. Each experimental period lasted $28 \mathrm{~d}$ of which $14 \mathrm{~d}$ were for adaptation and $14 \mathrm{~d}$ for collection of production data. Cows were housed in tie stalls for the duration of the experiment and had free access to water. Recombinant bST was injected (500 mg of Posilac, Monsanto, St. Louis, MO) every $14 \mathrm{~d}$ to all animals starting on the first day of the experiment. Animal care and experimental procedures met the requirements of the Institutional Animal Care and Use Committee of the University of WisconsinMadison (Research Animal Resources Center, protocol \# A-07-3400-A00286). For health reasons unrelated to the experiment, one intact cow was removed during period 1, and one cannulated cow was removed during period 3 but immediately replaced.

Experimental diets were fed as TMR and contained (DM basis) $20 \%$ alfalfa silage, $35 \%$ corn silage, and $45 \%$ concentrate, of which rolled high-moisture shelled corn was the main component. Diets differed in the content of $\mathrm{CP}$ and protein supplements (DM basis): $\operatorname{diet} \mathrm{A}$ ) $15.6 \%$ CP, 3.7\% SSBM, plus 4.5\% ESBM (SoyPlus, West Central Soy, Ralston, IA); diet B) $16.6 \%$ CP, 9.6\% SSBM, plus 0\% ESBM; diet C) $16.6 \% \mathrm{CP}, 4.6 \% \mathrm{SSBM}$, plus 5.9\% ESBM; and diet D) $17.6 \% \mathrm{CP}, 11.7 \% \mathrm{SSBM}$, plus 0\% ESBM. The SSBM and ESBM fed in the trial were estimated to have 30 and 59\% RUP, respectively, using the inhibitor in vitro assay (Broderick et al., 2004). All diets contained $2.5 \%$ roasted soybeans. The TMR were fed once daily at about $1200 \mathrm{~h}$ for ad libitum intake. Orts were collected and their weights recorded daily about $1 \mathrm{~h}$ before feeding. Amounts of feed offered were adjusted daily to yield 5 to $10 \%$ orts. Samples (about $0.5 \mathrm{~kg}$ ) of alfalfa silage, corn silage, rolled highmoisture shelled corn, and orts were collected daily, stored at $-20^{\circ} \mathrm{C}$, and composited weekly. Samples of SSBM, ESBM, and roasted soybeans were collected weekly. Subsamples from feeds and orts were dried at $60^{\circ} \mathrm{C}$ for $48 \mathrm{~h}$ and the as-fed compositions of the TMR were adjusted weekly. Intake of DM was corrected for orts and recorded daily throughout the experiment.

Once dried, feed subsamples were ground through a 1-mm screen (Wiley mill, Arthur H. Thomas, Philadel- phia, PA) and then analyzed for $\mathrm{DM}$ at $105^{\circ} \mathrm{C}$ (AOAC, 1980) and total N (Leco 2000, Leco Instruments, Inc., St. Joseph, MI). Diets were adjusted weekly to the desired $\mathrm{CP}$ content (total $\mathrm{N} \times 6.25$ ) by only altering dietary high-moisture corn, SSBM, and ESBM levels to obtain the target CP concentrations. Subsamples of SSBM and ESBM from wk 3 and 4 of each period were analyzed for total fat (method 920.39; AOAC, 1997; Dairyland Laboratories, Arcadia, WI). Ground feed subsamples also were analyzed sequentially for NDF and ADF (Van Soest et al., 1991) using heat-stable amylase and sodium sulfite (Hintz et al., 1995) in an Ankom Fiber Analyzer (Ankom Technology Corp., Fairport, NY). The $\mathrm{N}$ content of NDF residues was analyzed by combustion assay (Leco Instruments Inc.). Ash and OM contents of feeds were determined as described by AOAC (1980). Weekly samples of alfalfa silage and corn silage were thawed, water extracts prepared (Muck, 1987), and $\mathrm{pH}$ measured. Extracts were then deproteinized and analyzed for NPN (Muck, 1987) using a combustion assay (VarioMax CN analyzer; Elementar Analysensysteme $\mathrm{GmbH}$, Hanau, Germany). The concentration of nutrients for the dietary ingredients reported in Table 1 are averages from all samples of each ingredient collected throughout the 16 experimental weeks. The chemical compositions of the diets reported in Table 2 were computed based on the amounts of DM and nutrients contributed by each feed ingredient to the TMR, and are averages from all 16 experimental weeks.

Cows were weighed on 3 consecutive days at the beginning and the end of each experimental period. Cows were milked twice daily and milk weights were recorded at each milking. On d 20 and 27 of each period, a.m. and p.m. samples of milk were collected, preserved with 2-bromo-2-nitropropane-1,3-diol, and analyzed for fat, protein, lactose, and total solids by infrared methods (AgSource Laboratory, Verona, WI). Composite milk samples were prepared from each cow each sampling day by mixing 5 -mL subsamples from consecutive a.m. and p.m. samples. Composites were deproteinized (Shahani and Sommer, 1951) and analyzed for MUN by an automated colorimetric assay (Broderick and Clayton, 1997) adapted to flow-injection analysis (Lachat QuickChem 8000 FIA; Zellweger Analytical, Milwaukee, WI).

On d 27 of each period, samples of rumen fluid were collected from two locations in the midventral ruminal sac of cannulated cows starting at $1200 \mathrm{~h}$ (just before feeding), and at $1,2,4,8,12,18$, and $24 \mathrm{~h}$ after feeding. Samples were withdrawn using a $60-\mathrm{mL}$ plastic syringe, which was connected to a metal filter probe. The probe comprised a filter, which was a cylinder $7.5 \mathrm{~cm}$ long and $1.8 \mathrm{~cm}$ in diameter with $1.0 \mathrm{~mm}$ diameter holes, welded to a 1-m metal tube with an internal diameter of $0.5 \mathrm{~cm}$. The $\mathrm{pH}$ of the samples was mea- 
Table 1. Composition of feeds ${ }^{1}$

\begin{tabular}{|c|c|c|c|c|c|c|c|c|c|c|c|c|}
\hline \multirow[b]{2}{*}{ Item } & \multicolumn{2}{|c|}{ Alfalfa silage } & \multicolumn{2}{|c|}{ Corn silage } & \multicolumn{2}{|c|}{ RHMSC } & \multicolumn{2}{|c|}{ SSBM } & \multicolumn{2}{|c|}{ ESBM } & \multicolumn{2}{|c|}{ RSB } \\
\hline & Mean & SD & Mean & $\mathrm{SD}$ & Mean & SD & Mean & SD & Mean & SD & Mean & $\mathrm{SD}$ \\
\hline $\mathrm{DM}, \%$ & 45.5 & 5.7 & 31.6 & 0.8 & 73.9 & 1.0 & 89.2 & 0.4 & 90.0 & 1.1 & 97.0 & 0.7 \\
\hline Ash, $\%$ of DM & 12.9 & 2.5 & 4.88 & 0.62 & 1.42 & 0.63 & 6.95 & 0.85 & 6.19 & 0.65 & 5.20 & 0.71 \\
\hline $\mathrm{NDF}, \%$ of $\mathrm{DM}$ & 39.6 & 2.3 & 42.2 & 2.2 & 10.0 & 1.5 & 8.86 & 1.16 & 16.5 & 1.4 & 22.4 & 2.6 \\
\hline $\mathrm{ADF}, \%$ of $\mathrm{DM}$ & 29.6 & 1.6 & 23.6 & 1.3 & 2.33 & 0.32 & 4.57 & 0.78 & 7.47 & 0.85 & 5.11 & 1.00 \\
\hline $\mathrm{NDIN}^{2} \%$ of DM & 0.43 & 0.09 & 0.12 & 0.01 & 0.06 & 0.02 & 0.07 & 0.02 & 0.72 & 0.13 & 1.50 & 0.27 \\
\hline $\mathrm{RUP}^{3} \%$ of total CP & - & - & - & - & - & - & 30 & 1 & 59 & 2 & - & - \\
\hline Fat content, $\%$ of DM & - & - & - & - & - & - & 1.8 & 0.3 & 7.0 & 0.6 & - & - \\
\hline
\end{tabular}

${ }^{1} \mathrm{ESBM}=$ Expeller soybean meal; RHMSC = rolled high-moisture shelled corn; RSB = roasted soybeans; and SSBM = solvent-extracted soybean meal.

${ }^{2} \mathrm{NDIN}=$ Neutral detergent insoluble N.

${ }^{3}$ RUP estimated using the inhibitor in vitro procedure (Broderick et al., 2004).

sured immediately and $20 \mathrm{~mL}$ of rumen fluid was acidified with $0.4 \mathrm{~mL}$ of $50 \%$ ( $\mathrm{vol} / \mathrm{vol}$ ) sulfuric acid and stored at $-20^{\circ} \mathrm{C}$ for later analysis of VFA (Brotz and Schaefer, 1987), and total free $\mathrm{AA}$ and $\mathrm{NH}_{3}$ concentrations (Broderick et al., 2004).

Table 2. Composition of diets

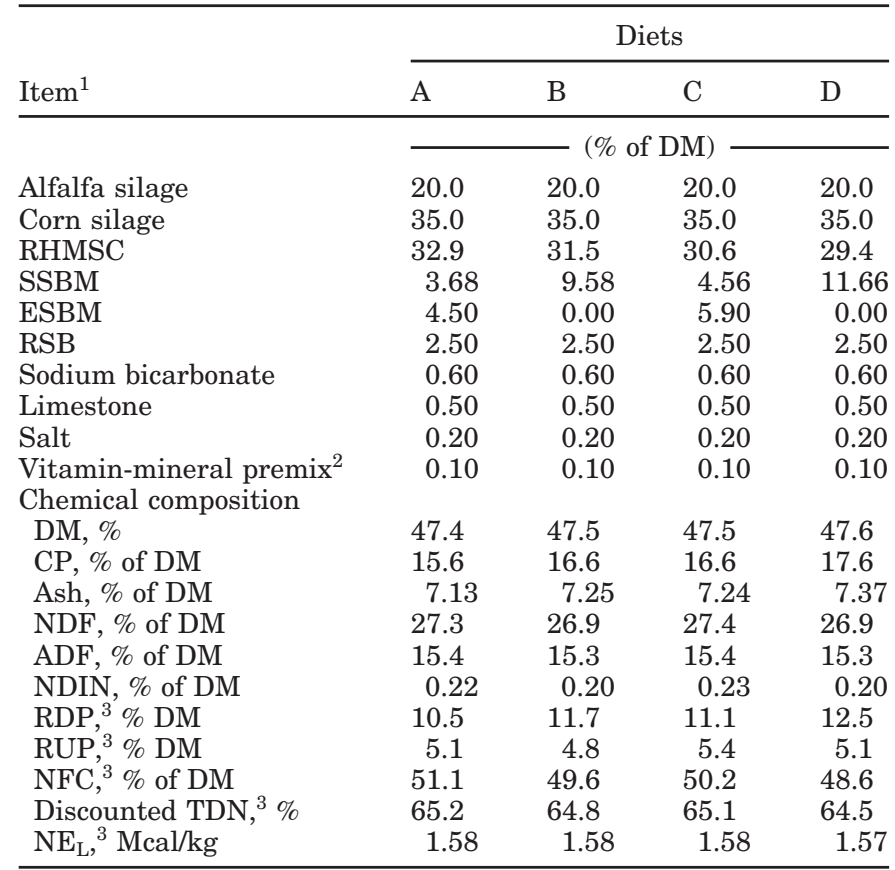

${ }^{1} \mathrm{ESBM}=$ Expeller soybean meal; NDIN = neutral detergent insoluble N; RHMSC = rolled high-moisture shelled corn; RSB = roasted soybeans; $\mathrm{SSBM}=$ solvent-extracted soybean meal; TDN = total digestible nutrients.

${ }^{2}$ Provided per kilogram of DM: $56 \mathrm{mg}$ of $\mathrm{Zn}, 46 \mathrm{mg}$ of Mn, $22 \mathrm{mg}$ of Fe, $12 \mathrm{mg}$ of $\mathrm{Cu}, 0.9 \mathrm{mg}$ of I, $0.4 \mathrm{mg}$ of Co, $0.3 \mathrm{mg}$ of Se, 6,440 IU of vitamin A, 2,000 IU of vitamin D, and 16 IU of vitamin $E$.

${ }^{3}$ Computed using NRC (2001) model based on actual composition of feeds, actual DMI, milk yield and composition, and overall average $\mathrm{BW}$ of the cows $(706 \mathrm{~kg})$.
Blood was also sampled on d 27 of each period from the coccygeal artery or vein into heparinized evacuated tubes from each cow at about $4 \mathrm{~h}$ after feeding. Heparinized blood was held on ice until being brought to the laboratory. Blood was deproteinized by mixing $1.25 \mathrm{~mL}$ of $25 \%$ (wt/vol) TCA with $5 \mathrm{~mL}$ of whole blood and then centrifuging $\left(15,000 \times g, 4^{\circ} \mathrm{C}, 15 \mathrm{~min}\right)$; supernatants were stored at $-20^{\circ} \mathrm{C}$ until analyzed for urea (Broderick and Clayton, 1997).

Urine and fecal grab samples were collected on d 26 of each period about $6 \mathrm{~h}$ before and after feeding. Fecal samples were dried in a forced draft oven at $60^{\circ} \mathrm{C}$ for $72 \mathrm{~h}$, ground through a 1-mm screen (Wiley mill), equal amounts of DM from a.m. and p.m. samples from each cow were mixed, and composites were analyzed for DM, ash, $\mathrm{OM}, \mathrm{NDF}, \mathrm{ADF}$, and $\mathrm{N}$ as described earlier for feeds. Total tract apparent digestibility of nutrients was estimated using the indigestible $\mathrm{ADF}$ content (ADF remaining after 12-d in situ incubations; Huhtanen et al., 1994) in feces and TMR as an internal marker. Urine samples $(15 \mathrm{~mL})$ were acidified with $60 \mathrm{~mL}$ of $0.072 \mathrm{~N}$ $\mathrm{H}_{2} \mathrm{SO}_{4}$ and immediately stored at $-20^{\circ} \mathrm{C}$. After thawing, urine samples were analyzed for total $\mathrm{N}$ by combustion assay (VarioMax CN analyzer), and for urea (Broderick and Clayton, 1997) and creatinine (Oser, 1965) using flow-injection analysis (Lachat Quick-Chem 8000 FIA). Urine volume was computed using creatinine as a marker and assuming creatinine excretion of $29 \mathrm{mg} / \mathrm{kg}$ of BW per day (Valadares et al., 1999). Allantoin (Vogels and van der Grift, 1970) and uric acid (kit no. 1830, Thermo DMA) were also determined in urine using assays adapted to a 96-well plate reader. Bacterial CP flow from the rumen was computed from urinary allantoin as described by Vagnoni et al. (1997) using the bacterial N:total purine ratio reported by Reynal et al. (2003). 


\section{Statistical Analyses}

All data were analyzed as a Latin square design using the Proc Mixed procedures of SAS (SAS Institute, 1999). Model sums of squares for data with only one observation per cow per period (including production traits that were single means from the last $14 \mathrm{~d}$ of each period) were separated into overall mean, cow (within square), square, period, treatment (effect of diet), square $\times$ treatment interaction, and overall error. All variables were considered fixed, except cow (within square) and overall error, which were considered random. The interaction term square $\times$ treatment was removed from the model when $P>0.25$. Model sums of squares for ruminal data collected at different times after feeding $(\mathrm{pH}$ and concentrations of $\mathrm{NH}_{3}-\mathrm{N}$, total free $\mathrm{AA}$, and VFA) were separated into overall mean, cow, period, treatment (effect of diet), whole plot error, hours postfeeding (repeated measures), hours postfeeding $\times$ treatment interaction, and subplot error. The repeated measures analyses were performed using the $\mathrm{SP}(\mathrm{POW})$ structure of SAS.

\section{RESULTS AND DISCUSSION}

\section{Composition of Diets}

The alfalfa silage and corn silage averaged 45.5 and $31.6 \% \mathrm{DM}$ and contained (DM basis) 22.9 and $8.43 \%$ $\mathrm{CP}, 39.6$ and $42.2 \% \mathrm{NDF}$, and 29.6 and $23.6 \% \mathrm{ADF}$, respectively (Table 1). The NPN content of alfalfa silage was $46 \%$ of total $\mathrm{N}$, which was lower than the values normally found for this forage (Broderick, 1995), and its extract $\mathrm{pH}$ was 4.70 . Corn silage NPN averaged $57 \%$ of total $\mathrm{N}$ and its extract $\mathrm{pH}$ was 3.76. These data indicated that both forages were of high quality. The lower proportion of NPN in alfalfa silage may have improved use of CP by the cows (Nagel and Broderick, 1992). Rolled high-moisture shelled corn, SSBM, ESBM, and roasted soybeans averaged 8.41, 55.8, 48.4, and $41.2 \% \mathrm{CP}$, respectively. The low variation in $\mathrm{CP}$ content of these feeds made it possible to maintain the diets close to target CP concentrations while keeping the proportions of SSBM and ESBM almost constant throughout the trial (Table 2). Dietary NDF levels were within the ranges recommended by NRC (2001) for these types of diets. However, dietary ADF averaged 1.7 percentage units lower than the minimum concentration, and estimated NFC averaged 5.9 percentage units higher than the maximum concentration, recommended by NRC (2001). The higher NFC contents in all the diets may have stimulated greater microbial protein formation (Stokes et al., 1991) because ruminal $\mathrm{pH}$ was always above 6 for all experimental diets.

\section{Production}

Generally, the production traits measured in this trial were not significantly affected $(P>0.05)$ by diet (Table 3). However, milk yield tended $(P=0.08)$ to be lower for diet A compared with diet B, suggesting that feeding greater RUP as ESBM would not compensate for reducing dietary CP from 16.6 to $15.6 \%$. Trends were also detected for higher DM intake $(P=0.09)$ and weight gain $(P=0.10)$, and lower milk yield/DMI $(P=$ 0.06 ) in cows fed diet $\mathrm{D}$ compared with $\operatorname{diet} \mathrm{B}$, indicating that increased dietary $\mathrm{CP}$ promoted higher intake without improving production. Broderick (2003) reported that DMI of lactating dairy cows increased linearly when dietary CP was increased from 15.1 to $18.4 \%$ of DM; however, as in the present study, milk yield was not improved with more than $16.6 \% \mathrm{CP}$, resulting in lower feed efficiency. Similarly, Sannes et al. (2002) observed a significant increase in DMI when dietary CP was increased from 17.2 to $19.1 \%$, but milk yield was not increased. Supplementation with ESBM did not improve milk yield/DMI, either when the diets differed (diet A vs. B) or had equal (diet B vs. C) CP content. Therefore, ESBM and SSBM appeared to have similar effects on availability of dietary energy. Feeding RUP as ESBM resulted in a higher $(P \leq 0.03)$ milk lactose content.

The lack of effect of ESBM supplementation on DMI is consistent with previous results. Diets containing alfalfa silage as the sole forage gave similar DMI when either ESBM or SSBM were fed at equal CP content (Broderick et al., 1990; Hoffman et al., 1991) or when diets containing ESBM had lower CP content (Broderick et al., 1990). Titgemeyer and Shirley (1997) and Reynal and Broderick (2003) reported no differences in DMI between cows supplemented with ESBM or SSBM in diets containing forage from both alfalfa and corn silage.

Milk production responses to RUP supplementation from ESBM have been inconsistent. Reynal and Broderick (2003) reported that cows fed diets containing $44 \%$ corn silage and $22 \%$ alfalfa silage produced $1.4 \mathrm{~kg} / \mathrm{d}$ more milk on ESBM vs. SSBM. Similarly, in 2 out of 3 experiments, Broderick et al. (1990) found that supplementation of ESBM in diets containing alfalfa silage as the sole forage improved milk production by about $1 \mathrm{~kg} / \mathrm{d}$ compared with SSBM. In those trials (Broderick et al., 1990), the NPN in alfalfa silage accounted for more than $40 \%$ of dietary CP. Therefore, the inclusion of ESBM might have counteracted the adverse effects from high levels of NPN on CP use (Nagel and Broderick, 1992). In the present experiment, forage NPN contributed on average only $23 \%$ of dietary CP across all diets. Other researchers have reported no benefit in 
Table 3. Effect of dietary protein source (expeller soybean meal, ESBM) and CP concentration on milk production and composition

\begin{tabular}{|c|c|c|c|c|c|c|c|c|}
\hline \multirow[b]{2}{*}{ Item } & \multicolumn{4}{|c|}{ Diets $^{1}$} & \multirow[b]{2}{*}{$\mathrm{SE}^{2}$} & \multicolumn{3}{|c|}{ Contrasts ( $P$-value $)$} \\
\hline & A & B & $\mathrm{C}$ & $\mathrm{D}$ & & A vs. B & B vs. C & B vs. D \\
\hline Intake of DM, kg/d & 25.2 & 25.6 & 25.5 & 26.4 & 0.7 & 0.39 & 0.81 & 0.09 \\
\hline Milk yield, kg/d & 38.8 & 40.0 & 40.3 & 40.1 & 1.3 & 0.08 & 0.68 & 0.91 \\
\hline $3.5 \%$ FCM, kg/d & 41.1 & 42.2 & 42.9 & 42.7 & 1.4 & 0.21 & 0.44 & 0.59 \\
\hline Milk/DMI & 1.53 & 1.56 & 1.58 & 1.51 & 0.04 & 0.23 & 0.61 & 0.06 \\
\hline BW gain, $\mathrm{kg} / \mathrm{d}$ & 0.68 & 0.53 & 0.53 & 0.73 & 0.09 & 0.23 & 1.00 & 0.10 \\
\hline \multicolumn{9}{|c|}{ Milk composition and yield } \\
\hline Fat, \% & 4.03 & 3.98 & 4.00 & 4.00 & 0.10 & 0.59 & 0.79 & 0.80 \\
\hline Fat yield, kg/d & 1.50 & 1.54 & 1.57 & 1.56 & 0.06 & 0.37 & 0.43 & 0.54 \\
\hline Protein, \% & 3.23 & 3.24 & 3.20 & 3.28 & 0.04 & 0.56 & 0.14 & 0.26 \\
\hline Protein yield, kg/d & 1.21 & 1.26 & 1.24 & 1.27 & 0.04 & 0.11 & 0.54 & 0.76 \\
\hline Lactose, \% & 4.87 & 4.83 & 4.89 & 4.85 & 0.04 & 0.03 & $<0.01$ & 0.34 \\
\hline Lactose yield, $\mathrm{kg} / \mathrm{d}$ & 1.87 & 1.90 & 1.92 & 1.92 & 0.07 & 0.44 & 0.71 & 0.74 \\
\hline SNF, $\%$ & 8.99 & 8.97 & 8.98 & 9.01 & 0.05 & 0.45 & 0.67 & 0.12 \\
\hline SNF yield, kg/d & 3.42 & 3.52 & 3.51 & 3.54 & 0.11 & 0.26 & 0.97 & 0.75 \\
\hline
\end{tabular}

${ }^{1}$ Diets: $\mathrm{A}=15.6 \% \mathrm{CP}, 4.5 \% \mathrm{ESBM} ; \mathrm{B}=16.6 \% \mathrm{CP}, 0 \% \mathrm{ESBM} ; \mathrm{C}=16.6 \% \mathrm{CP}, 5.9 \% \mathrm{ESBM} ;$ and $\mathrm{D}=17.6 \%$ CP, $0 \%$ ESBM.

${ }^{2}$ Standard error of the least squares means.

milk production from supplementing ESBM compared with SSBM in diets based either on alfalfa silage (Hoffman et al., 1991) or alfalfa (silage or hay) plus corn silage (Ellison Henson et al., 1997; Titgemeyer and Shirley, 1997).

The lack of dramatic effect of dietary CP content on production was not surprising. Leonardi et al. (2003) and Olmos Colmenero and Broderick (2006a) found no effect $(P>0.05)$ of increasing dietary $\mathrm{CP}$ content on milk yield. Although milk yield was greater when $\mathrm{CP}$ was increased by 1.5 and 0.9 percentage units on, respectively, diets high in alfalfa silage and corn silage, Wattiaux and Karg (2004) saw no effect of forage source or CP level on yields of FCM or milk protein. Moreover, Olmos Colmenero and Broderick (2006b) observed that diets ranging from 16.5 to $19.4 \% \mathrm{CP}$ gave rise to similar ruminal outflows of total NAN, which may explain the lack in production response to increasing dietary CP in these trials. However, Dinn et al. (1998) and Grummer et al. (1996) reported that milk production of early lactation cows was increased by 1.4 and $2.1 \mathrm{~kg} / \mathrm{d}$ when dietary CP was increased from 16.7 to 18.3 and from 17.0 to $19.0 \%$ of DM, respectively. Most of the cited trials were reversal studies with periods that were 4 wk or less in length. In a whole-lactation study, Wu and Satter (2000) found that feeding $17.4 \% \mathrm{CP}$ for the first 16 wk after calving, followed by $16.0 \% \mathrm{CP}$ for the remaining $28 \mathrm{wk}$, maximized yield of FCM. Increasing dietary CP to as high as $19.3 \%$ during the first $16 \mathrm{wk}$, or to $17.9 \% \mathrm{CP}$ during the last $28 \mathrm{wk}$, did not improve FCM yield. The NRC (2001) model predicted similar amounts of MP (2,460 and 2,505 g/d, respectively) and similar milk production ( $33 \mathrm{~kg} / \mathrm{d}$ of MP allowable milk) for both $\operatorname{diets} \mathrm{A}$ and $\mathrm{B}$, despite lower $\mathrm{CP}$ in $\operatorname{diet} \mathrm{A}$, because of the extra RUP from inclusion of ESBM. The NRC (2001) model also predicted greater RUP flow $(1,389 \mathrm{~g} / \mathrm{d})$ in cows fed diet C (16.6\% CP with ESBM) that should have increased milk yield $1.5 \mathrm{~kg} / \mathrm{d}$ compared with cows fed diet B (16.6\% CP without ESBM; 1,238 $\mathrm{g} / \mathrm{d}$ of predicted RUP flow). However, the lack of effect of supplemental ESBM in both cases suggested that use of the extra RUP may have been limited by insufficient absorption of Met, the AA most limiting in soybean protein for milk production (Broderick, 1994).

Actual milk yield in this experiment was, on average, $5.9 \mathrm{~kg} / \mathrm{d}$ greater than what the MP supply predicted by the NRC (2001) model would allow the cows to produce. Previously, we observed that the MP allowable milk predicted by NRC (2001) for 5 diets differing in CP content was $4.1 \mathrm{~kg} / \mathrm{d}$ lower than actual milk production (Olmos Colmenero and Broderick, 2006a). However, the NRC (2001) model also predicted ruminal outflows of bacterial CP that were, on average, $31 \%$ below the amounts measured in that trial using ${ }^{15} \mathrm{~N}$ as the microbial marker and omasal sampling (Olmos Colmenero and Broderick, 2006b). These results strongly suggested that underestimation of bacterial CP flow by the NRC (2001) model was responsible for underpredicting milk yield in the current study.

Reynal and Broderick (2003) and Ellison Henson et al. (1997) found no differences in milk fat and protein content and yield between cows supplemented with ESBM and SSBM. However, milk protein content sometimes was reduced (Titgemeyer and Shirley, 1997) and yield of lactose increased (Broderick et al., 1990) in cows supplemented with ESBM compared with SSBM. The higher lactose concentration observed in this study on $\operatorname{diets} \mathrm{A}$ and $\mathrm{C}$ compared with $\operatorname{diet} \mathrm{B}(P \leq 0.03)$ may be 
explained by a greater supply of absorbed AA from RUP of ESBM that would have become available for gluconeogenesis (Danfaer, 1994). The alteration in milk lactose concentration was, however, very small.

In agreement with the present findings, several researchers have reported no effect of dietary CP on milk fat and protein (the most economically important milk components) content and yield (Cunningham et al., 1996; Sannes et al., 2002; Arieli et al., 2004). However, Broderick (2003) found that yields of fat and protein were improved by increasing dietary CP from 15.1 to $16.7 \%$ but with no further increases at $18.4 \% \mathrm{CP}$. Olmos Colmenero and Broderick (2006a) found that fat and protein yields showed linear $(P=0.06)$ and quadratic $(P=0.09)$ trends, respectively, when dietary $\mathrm{CP}$ was increased from 13.5 to $19.4 \%$; both traits reached maxima (1.18 and $1.24 \mathrm{~kg} / \mathrm{d}$, respectively) at $16.5 \% \mathrm{CP}$. Milk protein content has been increased (Broderick, 2003) or decreased (Leonardi et al., 2003) in response to higher levels of dietary CP. Higher fat content of milk (Leonardi et al., 2003; Olmos Colmenero and Broderick, 2006a) in response to increasing levels of dietary CP also has been reported.

\section{Ruminal Metabolites and Total Tract Digestibility}

Ruminal concentration of $\mathrm{NH}_{3}-\mathrm{N}$ was not different between diets supplemented with ESBM and SSBM; however, it was significantly higher $(P=0.04)$ for diet $\mathrm{D}$ compared with diet $\mathrm{B}$ (Table 4 ). Moreover, isovalerate concentration tended $(P=0.08)$ to be higher on $\operatorname{diet} \mathrm{D}$ than on diet B. Diet D had a higher proportion of SSBM compared with diet B and, based on NRC (2001) predictions, diet $\mathrm{D}$ supplied greater RDP (12.5\% of dietary $\mathrm{DM})$ than diet B (11.7\%). Therefore, higher amounts of AA resulting from protein degradation probably were deaminated, leading to higher ruminal concentrations of $\mathrm{NH}_{3}-\mathrm{N}$ and isovalerate, another by-product of $\mathrm{AA}$ deamination in the rumen. Sannes et al. (2002) found that concentrations of both $\mathrm{NH}_{3}$ and branched-chain VFA increased in response to increasing dietary $\mathrm{CP}$ from 17.2 to $19.1 \%$. Olmos Colmenero and Broderick (2006a) found that the concentrations of ruminal $\mathrm{NH}_{3}$ $\mathrm{N}$ increased linearly from 6.1 to $12.8 \mathrm{mg} / \mathrm{dL}$ when dietary CP was increased from 13.5 to $19.4 \%$; however, concentrations of branched-chain VFA only increased with the first increment, from 13.5 to $15.0 \%$, with no further response at higher $\mathrm{CP}$. The similar $\mathrm{NH}_{3}-\mathrm{N}$ concentrations on diets $\mathrm{A}$ and $\mathrm{B}$ in the present study were surprising because diet A had lower $\mathrm{CP}$, and because inclusion of ESBM in diet A decreased its predicted RDP supply (NRC, 2001) by 1.2 percentage units (Table 2). However, if additional MP was not utilized for milk protein secretion due to inadequate Met (Broderick,
1994), at least a portion of the $\mathrm{N}$ would have recycled to the rumen as urea.

Other ruminal metabolites were not significantly affected by either ESBM supplementation or by dietary CP content (Table 4). Results from earlier studies also showed that inclusion of RUP as ESBM in the diet resulted in similar ruminal $\mathrm{pH}$ and concentrations of free AA and VFA compared with diets containing SSBM, either at similar (Broderick et al., 1990; Reynal and Broderick, 2003) or higher dietary CP contents (Broderick et al., 1990). However, Ellison Henson et al. (1997) reported higher acetate and lower propionate concentrations in ruminal fluid for ESBM compared with SSBM. As in the present experiment, Grummer et al. (1996) found no effect on ruminal VFA concentrations when dietary $\mathrm{CP}$ was increased. Cunningham et al. (1996) reported that only acetate increased in response to higher dietary CP, whereas Olmos Colmenero and Broderick (2006a) found that acetate increased linearly, and propionate quadratically, when dietary CP increased from 13.5 to $19.4 \%$.

Ruminal $\mathrm{pH}$ for the 4 experimental diets remained above 6.0 at all 8 time points throughout the daily feeding cycle, indicating that all cows had a satisfactory ruminal environment for nutrient fermentation, including fiber digestion (Hoover, 1986). This probably explains why apparent total tract digestibility of nutrients was largely unaffected by diet. Others have observed effects of dietary protein on ruminal and total tract digestibility. Reynal and Broderick (2003) reported that apparent ruminal digestibility of $\mathrm{OM}$ and $\mathrm{NDF}$ was not influenced by either dietary CP content or source (ESBM vs. SSBM); however, apparent total tract digestibility of DM, NDF, and ADF were significantly higher $(P<0.05)$ for SSBM compared with ESBM. When both protein supplements were compared with a lower CP diet, only SSBM promoted the greater digestion. Olmos Colmenero and Broderick (2006b) found that apparent ruminal digestibilities of DM, OM, $\mathrm{NDF}$, and ADF were not different in response to dietary CP ranging from 13.5 to $19.4 \%$; however, apparent total tract digestibility of these nutrients showed quadratic responses to $\mathrm{CP}$, with maxima occurring on diets containing 15.0 to $16.5 \% \mathrm{CP}$ (Olmos Colmenero and Broderick, 2006b). Broderick (2003) also found that total tract digestibility of DM and OM was not different on diets ranging from 15.1 to $18.4 \% \mathrm{CP}$, but $\mathrm{NDF}$ and $\mathrm{ADF}$ digestibilities were significantly higher on diets containing $18.4 \% \mathrm{CP}$ than either 15.1 or $16.7 \% \mathrm{CP}$. Broderick (2003) suggested that the higher fiber digestibility at $18.4 \% \mathrm{CP}$ might have occurred in response to the higher RDP intake. 
Table 4. Effect of dietary protein source (expeller soybean meal, ESBM) and CP concentration on ruminal metabolites and apparent total tract digestibility of nutrients

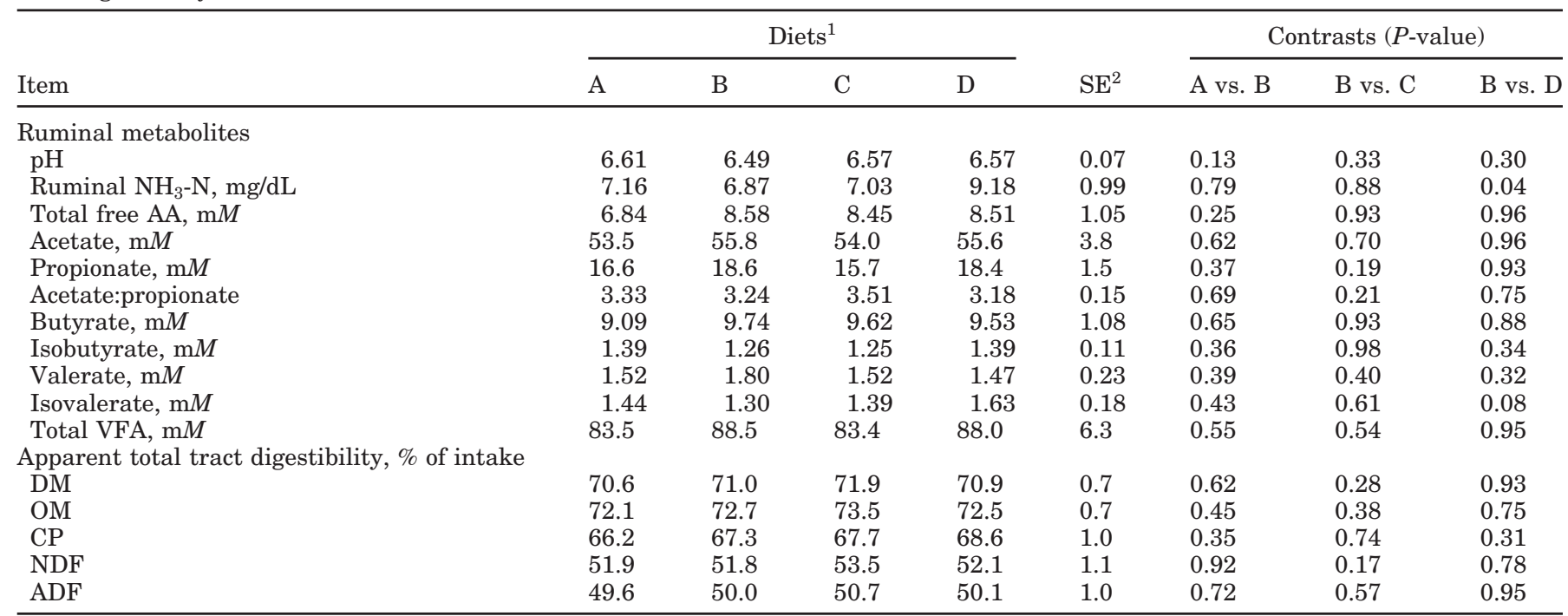

${ }^{1}$ Diets: $\mathrm{A}=15.6 \% \mathrm{CP}, 4.5 \% \mathrm{ESBM} ; \mathrm{B}=16.6 \% \mathrm{CP}, 0 \% \mathrm{ESBM} ; \mathrm{C}=16.6 \% \mathrm{CP}, 5.9 \% \mathrm{ESBM}$; and D = 17.6\% CP, $0 \% \mathrm{ESBM}$.

${ }^{2}$ Standard error of the least squares means.

\section{Nitrogen Metabolism}

Data on $\mathrm{N}$ metabolism are summarized in Table 5. As expected, $\mathrm{N}$ intake was higher for diet $\mathrm{B}$ compared with $\operatorname{diet} \mathrm{A}$, similar for diet $\mathrm{B}$ and $\mathrm{C}$, and higher for diet $\mathrm{D}$ compared with diet B. Milk protein $\mathrm{N}$ was not affected either by source or level of dietary CP. Higher
$\mathrm{N}$ intake and similar secretion of milk protein $\mathrm{N}$ for cows fed diet $\mathrm{D}(17.6 \% \mathrm{CP})$ compared with cows fed diet $\mathrm{B}(16.6 \% \mathrm{CP})$ resulted in efficiency (milk protein N/N intake) being decreased $(P<0.01)$ from 29.3 to $26.8 \%$. Olmos Colmenero and Broderick (2006a) and Broderick (2003) observed linear depressions on $\mathrm{N}$ efficiencies from, respectively, 36.5 to $25.4 \%$ and from 30.3 to $23.9 \%$

Table 5. Effect of dietary protein source (expeller soybean meal, ESBM) and CP concentration on N metabolism

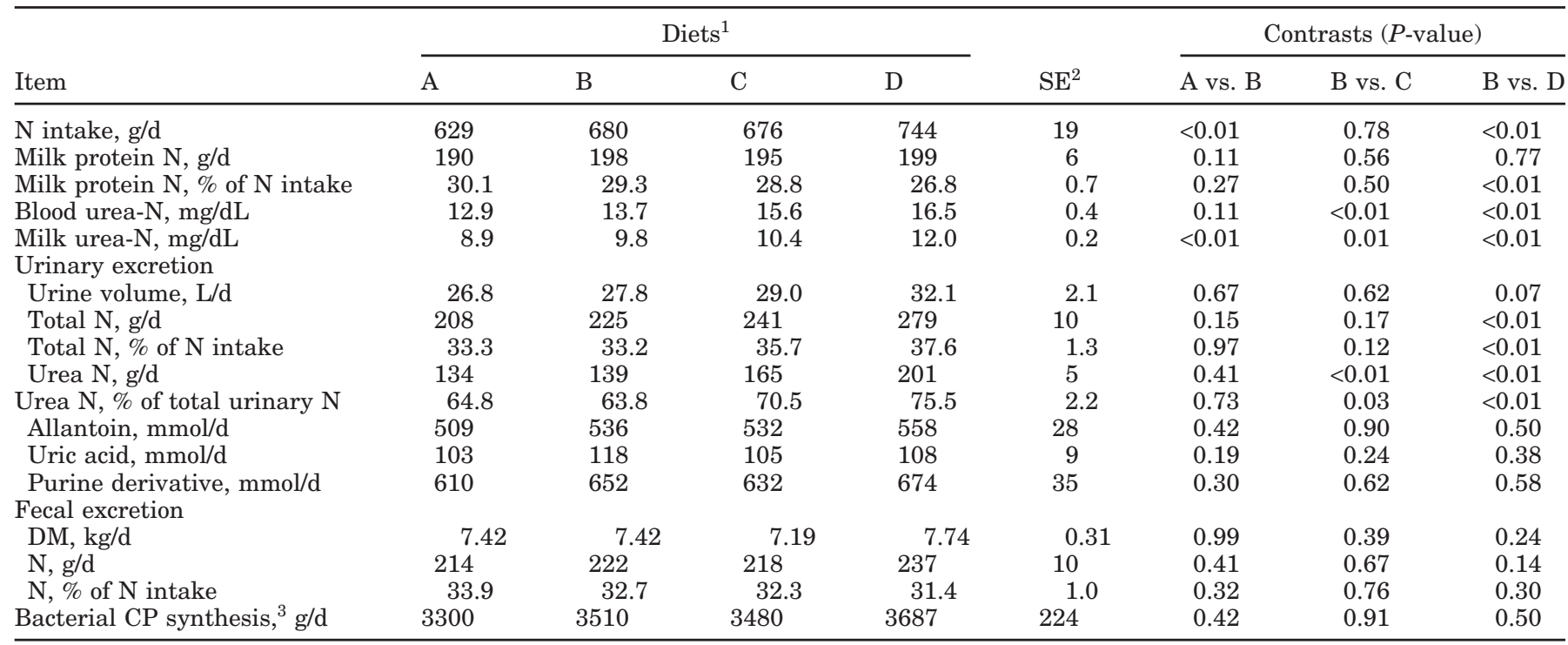

${ }^{1}$ Diets: $\mathrm{A}=15.6 \% \mathrm{CP}, 4.5 \% \mathrm{ESBM} ; \mathrm{B}=16.6 \% \mathrm{CP}, 0 \% \mathrm{ESBM} ; \mathrm{C}=16.6 \% \mathrm{CP}, 5.9 \% \mathrm{ESBM}$; and D = $17.6 \% \mathrm{CP}, 0 \% \mathrm{ESBM}$.

${ }^{2}$ Standard error of the least squares means.

${ }^{3}$ Calculation based on allantoin excretion in urine using the regression equation published by Vagnoni et al. (1997) and the bacterial N:purines ratios reported by Reynal et al. (2003). 
when dietary CP increased from 13.5 to $19.4 \%$ and from 15.1 to $18.4 \%$. In both studies, milk and protein yields were maximal at about $16.6 \% \mathrm{CP}$ with no further improvements at higher supplementation. These data clearly indicated that, when feeding diets based on alfalfa silage and corn silage with corn grain as the main starch source and SSBM meal as the main protein supplement, any increment in $\mathrm{CP}$ above $16.6 \%$ will result in wastage of dietary $\mathrm{N}$ and will contribute to $\mathrm{N}$ pollution.

Both BUN and MUN were significantly elevated ( $P$ $<0.01$ ) on diets C and D vs. diet B (Table 5). A similar concentration pattern for BUN and MUN was expected because blood urea rapidly equilibrates with milk (Gustafsson and Palmquist, 1993) and because these 2 variables are highly correlated (Broderick and Clayton, 1997). However, in spite of the fact that BUN was not different between diet A and diet B, MUN was significantly higher for diet B compared with $\operatorname{diet}$ A. Higher concentrations of MUN for diet B compared with diet $\mathrm{A}$ as well as for diet $\mathrm{D}$ compared with $\operatorname{diet} \mathrm{B}$ were expected because MUN is sensitive to dietary CP level (Broderick and Clayton, 1997). If it is considered that high concentrations of BUN indicated inefficient use of dietary protein (Broderick and Clayton, 1997), then similar BUN concentrations on $\operatorname{diets} \mathrm{A}$ and $\mathrm{B}$, and higher concentrations on diet $\mathrm{C}$ than $\operatorname{diet} \mathrm{B}$, suggested that ESBM supplementation contributed MP in the form of RUP (Table 2; NRC, 2001) that was not utilized because of insufficient Met content (Broderick, 1994). Additional MP not utilized for milk protein secretion but catabolized for gluconeogenesis will contribute to the urea pool. At least a portion of the $\mathrm{N}$ would be expected to recycle to the rumen and may have contributed to the similar $\mathrm{NH}_{3}-\mathrm{N}$ concentrations on diets $\mathrm{A}$, $\mathrm{B}$, and C (Table 4).

Reynal and Broderick (2003) reported that ESBM had no effect on BUN compared with SSBM in diets that contained $44 \%$ corn silage and $22 \%$ alfalfa silage. Moreover, when alfalfa silage was sole source of forage and the experimental diets contained similar $\mathrm{CP}$ contents, BUN and MUN were not different in response to ESBM or SSBM (Broderick et al., 1990).

Urine volume, urinary excretion of purine derivatives, estimated bacterial CP synthesis, and fecal DM and $\mathrm{N}$ excretion were not affected either by source or level of dietary CP (Table 5). Total urinary N excretion was not affected by source of protein but it was significantly higher $(P<0.01)$ for diet $\mathrm{D}$ vs. diet $\mathrm{B}$. Urinary excretion of urea $\mathrm{N}$ was not different between diets $\mathrm{A}$ and $\mathrm{B}$, but it was higher for diets $\mathrm{C}$ and $\mathrm{D}$ vs. diet $\mathrm{B}$. The trend $(P=0.07)$ for elevated urine volume on diet $\mathrm{D}$ compared with diet $\mathrm{B}$ agreed with earlier results (Olmos Colmenero and Broderick, 2006a) and indicated the greater urine volumes required for excreting excess
$\mathrm{N}$ in dairy cows (Holter et al., 1982). By increasing dietary CP from $16.6 \%$ on diet $\mathrm{B}$ to $17.6 \%$ on diet $\mathrm{D}$, the proportion of $\mathrm{N}$ consumed that was excreted in the urine increased from 33.2 to $37.6 \%$. Urinary urea $\mathrm{N}$ excretion also increased from $139 \mathrm{~g} / \mathrm{d}$ on diet B to 201 $\mathrm{g} / \mathrm{d}$ on diet $\mathrm{D}$, representing 63.8 and $75.5 \%$ of the total urinary N. Similar excretions of fecal N on diets B and $\mathrm{D}$ showed that almost all of the extra $\mathrm{N}$ consumed by cows fed diet $\mathrm{D}$ was excreted in the urine as urea. The similar excretions of urinary urea $\mathrm{N}$ for $\operatorname{diet} \mathrm{A}$ and $\operatorname{diet}$ $\mathrm{B}$, and the higher excretion of urinary urea $\mathrm{N}$ for diet $\mathrm{C}$ than diet $\mathrm{B}$, may reflect the greater catabolism of MP from ESBM as discussed earlier.

As expected, allantoin accounted for most of the purine derivatives excretion, averaging $83 \%$ across diets (Table 5). Bacterial CP synthesis, estimated from urinary allantoin, ranged from 3,300 to $3,687 \mathrm{~g} / \mathrm{d}$, and was not different for any of the contrasts. Therefore, it can be speculated that the similar milk production on all diets in this trial resulted in part from similar supplies of microbial protein.

\section{CONCLUSIONS}

Inclusion of RUP from ESBM in a diet with $15.6 \%$ $\mathrm{CP}(\operatorname{diet} \mathrm{A})$ did not sustain milk production as well as a diet with $16.6 \% \mathrm{CP}$ containing greater RDP from SSBM (diet B). Diets with the same CP content (16.6\% DM basis) but higher RDP (diet B) or higher RUP (diet C) yielded similar production and nutrient efficiencies, although RUP supplementation resulted in greater milk lactose content, BUN and MUN concentrations, and urinary excretion of urea $\mathrm{N}$. Increasing dietary $\mathrm{CP}$ content from 16.6 to $17.6 \%$ by increasing the amount of SSBM did not improve milk production, increased urinary $\mathrm{N}$ excretion, but tended to increase DMI, resulting in depressed $\mathrm{N}$ efficiency and a trend for lower feed efficiency (milk/DMI). Results from this trial suggested that RUP from ESBM might have been limited by insufficient absorption of Met. Under the conditions of this trial, $16.6 \% \mathrm{CP}$ was adequate to support milk and protein yields of 40 and $1.25 \mathrm{~kg} / \mathrm{d}$, respectively.

\section{ACKNOWLEDGMENTS}

The authors wish to thank the farm crew for harvesting and storing the feedstuffs used in this trial; Jill Davidson and the barn crew for feeding and animal care at the US Dairy Forage Center Research Farm (Prairie du Sac, WI); Santiago Reynal and Andre Brito for assisting with sampling; Wendy Radloff, Mary Becker, and Nelson Lobos for conducting laboratory analyses; and Peter Crump for assisting with statistical analyses. The first author also thanks Consejo Nacional 
de Ciencia y Tecnologia (CONACyT) Mexico, and Universidad de Guadalajara (Jalisco, Mexico) for partial financial support.

\section{REFERENCES}

Arieli, A., G. Adin, and I. Bruckental. 2004. The effect of protein intake on performance of cows in hot environmental temperatures. J. Dairy Sci. 87:620-629.

Association of Official Analytical Chemists. 1980. Official Methods of Analysis. 13th ed. AOAC, Washington, DC.

Association of Official Analytical Chemists. 1997. Official Methods of Analysis. 16th ed. AOAC, Washington, DC.

Broderick, G. A. 1994. Quantifying forage protein quality. Pages 200228 in Forage Quality, Evaluation, and Utilization. G. C. Fahey Jr., M. D. Collins, D. R. Mertens, and L. E. Moser, ed. Am. Soc. Agron., Madison, WI.

Broderick, G. A. 1995. Desirable characteristics of forage legumes for improving protein utilization in ruminants. J. Anim. Sci. 73:2760-2773.

Broderick, G. A. 2003. Effects of varying dietary protein and energy levels on the production of lactating dairy cows. J. Dairy Sci. 86:1370-1381.

Broderick, G. A., and M. K. Clayton. 1997. A statistical evaluation of animal and nutritional factors influencing concentrations of milk urea nitrogen. J. Dairy Sci. 80:2964-2971.

Broderick, G. A., D. B. Ricker, and L. S. Driver. 1990. Expeller soybean meal and corn by-products versus solvent soybean meal for lactating dairy cows fed alfalfa silage as sole forage. J. Dairy Sci. 73:453-462.

Broderick, G. A., P. Udén, M. L. Murphy, and A. Lapins. 2004. Sources of variation in rates of in vitro rumen protein degradation. J. Dairy Sci. 87:1345-1359.

Brotz, P. G., and D. M. Schaefer. 1987. Simultaneous determination of lactic acid and volatile fatty acids in microbial fermentation extracts by gas-liquid chromatography. J. Microbiol. Methods 6:139-144.

Cunningham, K. D., M. J. Cecava, T. R. Johnson, and P. A. Ludden. 1996. Influence of source and amount of dietary protein on milk yield by cows in early lactation. J. Dairy Sci. 79:620-630.

Danfaer, A. 1994. Nutrient metabolism and utilization in the liver. Livest. Prod. Sci. 39:115-127.

Dinn, N. E., J. A. Shelford, and L. J. Fisher. 1998. Use of the Cornell Net Carbohydrate and Protein System and rumen-protected lysine and methionine to reduce nitrogen excretion from lactating dairy cows. J. Dairy Sci. 81:229-237.

Ellison Henson, J., D. J. Schingoethe, and H. A. Maiga. 1997. Lactational evaluation of protein supplements of varying ruminal degradabilities. J. Dairy Sci. 80:385-392.

Grummer, R. R., K. Slark, S. J. Bertics, M. L. Luck, and J. A. Barmore. 1996. Soybeans versus animal sources of rumen-undegradable protein and fat for early lactation dairy cows. J. Dairy Sci. 79:1809-1816

Gustafsson, A. H., and D. L. Palmquist. 1993. Diurnal variation of rumen ammonia, serum urea, and milk urea in dairy cows at high and low yields. J. Dairy Sci. 76:475-484.

Hintz, R. W., D. R. Mertens, and K. A. Albrecht. 1995. Effects of sodium sulfite on recovery and composition of detergent fiber and lignin. J. AOAC 78:16-22.

Hoffman, P. C., R. R. Grummer, R. D. Shaver, G. A. Broderick, and T. R. Drendel. 1991. Feeding supplemental fat and undegraded intake protein to early lactation dairy cows. J. Dairy Sci. 74:3468-3474.

Holter, J. B., J. A. Byrne, and C. G. Schwab. 1982. Crude protein for high milk production. J. Dairy Sci. 65:1175-1188.
Hoover, W. H. 1986. Chemical factors involved in ruminal fiber digestion. J. Anim. Sci. 69:2755-2766.

Huhtanen, P., K. Kaustell, and S. Jaakkola. 1994. The use of internal markers to predict total digestibility and duodenal flow of nutrients in cattle given 6 different diets. Anim. Feed Sci. Technol. 48:211-227.

Leonardi, C., M. Stevenson, and L. E. Armentano. 2003. Effect of two levels of crude protein and methionine supplementation on performance of dairy cows. J. Dairy Sci. 86:4033-4042.

Muck, R. E. 1987. Dry matter level effects on alfalfa silage quality. 1. Nitrogen transformations. Trans. ASAE 30:7-14.

Nagel, S. A., and G. A. Broderick. 1992. Effect of formic acid or formaldehyde treatment of alfalfa silage on nutrient utilization by dairy cows. J. Dairy Sci. 75:140-154.

National Research Council. 2001. Nutrient Requirements of Dairy Cows. 7th rev. ed. Natl. Acad. Sci., Washington, DC.

Olmos Colmenero, J. J., and G. A. Broderick. 2006a. Effect of dietary crude protein concentration on milk production and nitrogen utilization in lactating dairy cows. J. Dairy Sci. 89:1704-1712.

Olmos Colmenero, J. J., and G. A. Broderick. 2006b. Effect of dietary crude protein concentration on ruminal nitrogen metabolism in lactating dairy cows. J. Dairy Sci. 89:1694-1703.

Oser, B. L. 1965. Hawk's Physiological Chemistry. 14 ed. Blakiston Div., McGraw-Hill, New York, NY.

Reynal, S. M., and G. A. Broderick. 2003. Effects of feeding dairy cows protein supplements of varying ruminal degradability. J. Dairy Sci. 86:835-843.

Reynal, S. M., G. A. Broderick, S. Ahvenjarvi, and P. Huhtanen. 2003 Effect of feeding protein supplements of differing degradability on omasal flow of microbial and undegraded protein. J. Dairy Sci. 86:1292-1305.

Sannes, R. A., M. A. Messman, and D. B. Vagnoni. 2002. Form of rumen-degradable carbohydrate and nitrogen on microbial protein synthesis and protein efficiency of dairy cows. J. Dairy Sci. 85:900-908.

Santos, F. A. P., J. E. P. Santos, C. B. Theurer, and J. T. Huber. 1998. Effects of rumen-undegradable protein on dairy cow performance: A 12-year literature review. J. Dairy Sci. 81:3182-3213.

SAS Institute. 1999-2000. SAS/STAT User's Guide. Release 8.1. Cary, NC.

Shahani, K. M., and H. H. Sommer. 1951. The protein and nonprotein nitrogen fractions in milk. I. Methods of Analysis. J. Dairy Sci. 34:1003-1009.

Stokes, S. R., W. H. Hoover, T. K. Miller, and R. P. Manski. 1991. Impact of carbohydrate and protein levels on bacterial metabolism in continuous culture. J. Dairy Sci. 74:860-870.

Titgemeyer, E. C., and J. E. Shirley. 1997. Effect of processed grain sorghum and expeller soybean meal on performance of lactating cows. J. Dairy Sci. 80:714-721.

Vagnoni, D. B., G. A. Broderick, M. K. Clayton, and R. D. Hatfield. 1997. Excretion of purine derivatives by Holstein cows abomasally infused with incremental amounts of purines. J. Dairy Sci. 80:1695-1702

Valadares, R. F. D., G. A. Broderick, S. C. Valadares Filho, and M. K. Clayton. 1999. Effect of replacing alfalfa silage with high moisture corn on ruminal protein synthesis estimated from excretion of total purine derivatives. J. Dairy Sci. 82:2686-2696.

Van Soest, P. J., J. B. Robertson, and B. A. Lewis. 1991. Methods for dietary fiber, neutral detergent fiber and nonstarch polysacharides in relation to animal nutrition. J. Dairy Sci. 74:3583-3597.

Vogels, G. D., and C. van der Grift. 1970. Differential analyses of glyoxylate derivatives. Anal. Biochem. 33:143-157.

Wattiaux, M. A., and K. L. Karg. 2004. Protein level for alfalfa and corn silage-based diets: I. Lactational response and milk urea nitrogen. J. Dairy Sci. 87:3480-3491.

Wu, Z., and L. D. Satter. 2000. Milk production during the complete lactation of dairy cows fed diets containing different amounts of protein. J. Dairy Sci. 83:1042-1051. 